\title{
An alternative character education of "Warok" for the family: A local wisdom of Ponorogo community
}

\author{
Jauhan Budiwan \\ Education Faculty, Sunan Giri Ponorogo Islamic Institute of Religion, Ponorogo, Indonesia
}

\begin{abstract}
This research aimed to: 1). Conceptual description of "Warok" content as family education to improve children's character; 2 ). To find out the steps of "Warok" as an educational alternative to the character values of children in Ponorogo; 3) To find out the effectiveness of "Warok" as character education in the community in Ponorogo. This research is an analysis of literature-based qualitative descriptive studies of the value of the local wisdom of the people of Ponorogo which is complemented by elements of social psychology of constructivism as an effort to maximize community character education. The results of this study indicate that "Warok" is an educational teaching of the Ponorogo community that has developed in the community, which is formulated in 5 steps: Wani, Anulodho, Rumekso, Omber, Kulino, Warok as community education are very effective in improving children's character.
\end{abstract}

\section{KEYWORDS}

Warok; community; character; education; local wisdom

Received: 15 June 2021

Accepted: 24 June 2021

Published: 24 June 2021

\section{Introduction}

Education is a process of change, from unusual to ordinary, which is not good at being good and who is not skilled at being skilled. Education is a process of experience (Ebersohn, 2004). Because life is growth, education means helping the inner growth of man without being limited by age (Dewey, 2010). The process of growth is the process of adjusting to each phase and adding skills to one's development through education (Diknas, 2003). Education is also a means of building one's character. Education is to help develop each of the body and mind with something that allows the achievement of perfection.

According to (Dewey, 2010), education is forming a new human being through the mediation of character and nature, and by imitating the relics - old cultural heritage of human society. Character education is considered to be able to allow mutual respect between one group and another group so that a peaceful and harmonious life is created, because education is often seen as an instrument to make a change, especially relating to values and mental attitudes, referring to the effort to advance the character, character, inner strength, mind and body of children in harmony with nature and society.

The issue of character deterioration in society in several countries is a lot. Indicators of character deterioration, namely the increase in crime rates in children, the use of illegal drugs, adult films circulating freely and being consumed by school-age children are happening in education in Indonesia (Soekanto, 2017). The role of schools is no longer a good place for children's development and even becomes unsafe (Krismawati, 2018).

The community according to (Soekanto, 2017) generally has the following characteristics: a) Humans who live together, at least consist of two people; b) Mix or mingle for a long period of time. Gathering humans will create new humans. As a result of living together, communication systems and regulations arise that govern human relations; c) Be aware that they are a unit; d) A system of living together. The system of shared life raises culture because they feel themselves related to one another. The Ponorogo community (Krismawati, 2018) in general is very easy to understand cognitive knowledge through a culture that has developed long ago in the community. According to (Istiwianah, 2008), the people of Ponorogo also uphold the tradition that develops and is able to maintain it well from the flow of technological development but does not dissolve the character values of society. Like through the culture of Reyog, a tradition inherent in the identity of the community in Ponorogo.

From the results of the research (Budiawan, 2018), conducted in the junior high schools in Ponorogo through the questionnaires on 280 students from three different schools and various economic backgrounds. The

CONTACT Jauhan Budiwan Mauhan_budiwan@student.uns.ac.id 
questionnaires were formulated with the instruments and indicators focusing on seven levels of virtue. After calculating using the Likert scale (Sugiono, 2016), the results are as follows: Empathy by 73.6\%, conscience by 78.1\%, self-control by $76 \%$, respect by $39.6 \%$, kindness by $80.7 \%$, tolerance by $17.8 \%$, and justice by $83.5 \%$. From the results of the field study (Budiawan, 2018), the percentage of the lacking character values were respect and tolerance that need to be followed up for improvement.

\section{Methods}

Method this research is an analysis of literature-based qualitative descriptive studies of the value of the local wisdom of the people of Ponorogo which is complemented by elements of social psychology of constructivism as an effort to maximize community character education. Conceptual steps of community wisdom using literature studies and historical chronicle documents of Ponorogo land, while to find out the effectiveness of the concept of education that comes from the local wisdom of the community about Warok through interviews with some parents, teachers and community leaders. The subjects of this study were conducted in SMPN 1, SMPN 6 Ponorogo and SMPN Babadan Ponorogo.

\section{Results and discussion}

The results of Warok Conceptual. Warok is the name that becomes the characteristic of the city of Ponorogo. Even when Warok is mentioned, people would associate it with Ponorogo. The Chronicle of Ponorogo book (Poerwowijoyo, 1997) explains that in the 17th century the city of Ponorogo was previously known as the kingdom of Wengker, led by Ki Ageng Suryongalam. Ki Ageng Suryongalam, known as Ki Ageng Kutu, founded a hermitage that taught the knowledge of magic and mysticism. Most of his students became powerfully supernatural. What was taught by Ki Ageng was that who was able to meditate and avoid women would have perfect supernatural power.

After Ki Ageng died of illness, his followers and students were gathered by Batoro Katong to be prepared to become manggala negeri (protector of nation). The hermitage was used as a place to galvanize youth to become defence knights of the newly established region, Ponorogo with Batoro Katong as the first regent. These magic manggalas were then referred to as Warok, namely patriotic warriors, to defend the country and be virtuous, be honest in character, responsible, willing to sacrifice for the benefit of others, like to work hard selflessly, justly, and decisively, have lots of knowledge, be noble and have supernatural power (Poerwowijoyo, 1997).

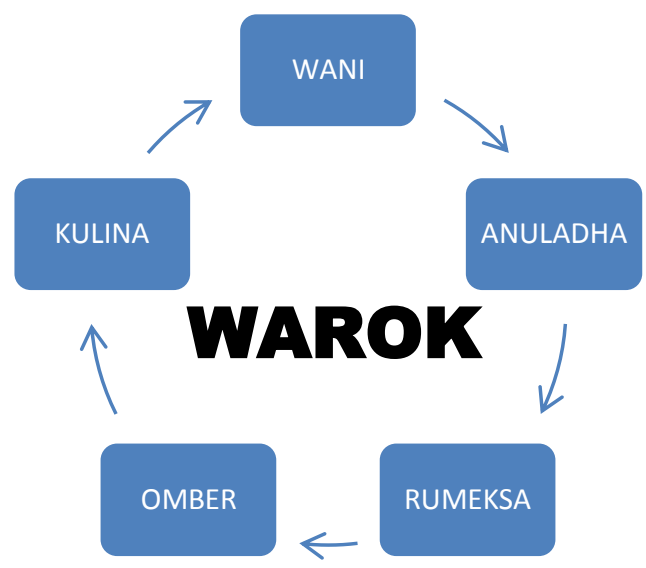

Figure 1. Warok as a concept of local wisdom education in the Ponorogo community

In the model of teaching in the family, there are steps taken which are named Warok.

\section{$W=$ Wani (Brave)}

The family teaches children to have courage and discipline in enforcing the rules and if they break them, they must be prepared to get sanctions (Poerwodarminto, 2008).

\section{A = Anuladha (Giving examples)}

Anuladha or tulodo is giving examples teaches modelling exemplary (Mardiwarsito, 1990). Parents must be role models for children and child development tends to mimic something he experiences (behaviouristic learning).

\section{$R=$ Rumeksa (Caring)}

Ngrekso means caring for always escorting, accompanying, and giving motivation to the children in order to achieve their goals (Poerwodarminto, 2008), referring to someone's psychological process that causes the occurrence 
of voluntary actions directed to achieve certain goals. In the family, parents can do things that make children motivated to do.

\section{$O=$ Omber (Expanding)}

Omber It means overflowing, expanding (teaches to broaden the horizons and associations of Universality) (Poerwodarminto, 2008). Parents invite their children for the discussion about the insights in addressing differences. They teach about the importance of religious tolerance, the necessity of multiculturalism, and respect for others across borders, religions, and cultures and value democracy.

\section{K = Kulina (Habit)}

Pakulinan refers to habits (teaching habituation that is well done by children based on legal order, religious order, or local wisdom (local wisdom/habituation) (Poerwodarminto, 2008). Habituation is something that is usually done repeatedly for ordinary things or is often done and has good values according to the religion and culture in society. Habituation must begin with children from childhood. Habituation that is done since childhood will bring hobbies and habits into a kind of customary habits that become an integral part of individual personality (Lickona, 2012).

Warok education steps in Ponorogo in improving the character of the community: Wani (Brave) The steps taken by parents in this content among others are: a) They show the obligations as religious people; b) They show the obligations as children in the family such as getting up early, cleaning the bed and yard; c) They provide rewards and punishments. The rewards can be in the forms of a complement or gift. The punishment can be not giving the pocket money; d) Parents instil the courage to accept sanctions if their children violate the rules; Anuladha (Giving Examples) The steps taken by parents in this content are as follows: a) Parents provide the examples of good behaviour based on the religion or cultural habits; b) They apply family togetherness at the dining table or in front of the television by teaching them how to behave and communicate; c) Parents ask about their children's school activities and assignments to be done; Rumeksa (Caring) This step is done in a way: a) Parents give attention and affection; b) Parents in the family protect and protect all children and are economically responsible; c) Parents provide guidance, direction, advice and motivation for children by stimulating siblings or successful neighboring children, for example, their children become police or others; d) Parents help students if they face difficulties in learning in school; Omber (Expanding) The steps taken by parents in this content are: a) Parents invite their children for the discussion about the insights in addressing differences and realizing that the differences are a gift given by God; $b$ ) They teach about the importance of religious tolerance, the necessity of multiculturalism, and respect for others across borders, religions, and cultures; c) The students apply helping each other, mutual cooperation, and social participation; Kulina (Habit) This step is done in a way: a) Parents educate behavioral habits such as carrying out religious and cultural teachings; b) Fostering harmonious relationships within the family; c) educate in speaking, behaving, dressing with attention to place and time; d) Parents find respect for the opinions of others.

The results of interviews with Ibnu Hajar (SMPN 1 teacher), Mustafidin (SMPN Babadan teacher), Malik (SMPN 6 teacher), Lukman, Sringatin and Rahmat (Parents of students) said that after the role of the family to teach the "warok" concept to children was very effective to instill character values and get better. The next step is the value of the local wisdom of the community will be disseminated by the school through religious education teachers to parents of students to teach the concept of "warok" in the family.

\section{Conclusion}

This study concluded that education originating from the local wisdom of the "warok" community was very effective in improving children's character and supporting learning in schools, so that efforts to instill character values in schools with family support would succeed.

There must be family support for the learning process at school. The school must also act by developing a collaborative learning model between school and family especially on character development subjects. With the support of the family, the researcher believes that the characters students will increase. This research is still far from perfection and the researchers hope that there will be inputs so that the results of this research can be better.

\section{Funding}

We thank to the Ministry of Religion of the Republic of Indonesia for providing funds to the author through the Decision Number: 4006/Dj.I/Dt.I.IV/PP.04/10/2018 about the recipient of the research assistance to improve the quality of the educators and education staff in the Ministry of Religion and Doctoral Program (S3). 


\section{References}

Budiwan, J., Hidayatullah, F., \& Yusuf, M. (2019). The profile of the public junior high school students' character values in Ponorogo, Indonesia. In IOP Conference Series: Earth and Environmental Science, 243(1), 012122. IOP Publishing.

Dewey, J. (2010). Democracy and education: An introduction to the philosophy of education. macmillan.

Diknas, UU No. 20 Tahun 2003 Tentang sistim pendidikan nasional. Jakarta: Diknas.

Ebersöhn, L., \& Eloff, I. (2004). Keys to educational psychology. Juta and Company Ltd.

Istiwianah, W. (2018). Strategi dan metode pelestarian kesenian reog ponorogo melalui seminar antar bangsa seni budaya dan desain. STANSA 2018, no. 2.

Krismawati, N. U., Warto, W., \& Suryani, N. (2018). Eksistensi warok dan gemblak di tengah masyarakat muslim ponorogo tahun 19601980. Religió: Jurnal Studi Agama-Agama, 8(1), 116-138.

Lickona, T. (2012). Education for character. Jakarta: Bumi Aksara.

Mardiwarsito, I. (1990). Kamus Jawa kuna Indonesia, IV. Nusa Tenggara Timur: Nusa Indah.

Maslow, A. H. (1981). Motivation and personality. Prabhat Prakashan.

Poerwodarminto. (2008). Kamus bahasa jawa (bausastra jawa). Yogyakarta: Kanisius.

Poerwowijoyo. (1997). Babad Tanah Ponorogo. Ponorogo: Kim an.

Sari, A. A. C., \& Sutomo, M. (2016). Peran pemerintah Kabupaten Ponorogo dalam pelembagaan kesenian reyog (The Role of Ponorogo local government in the reyog institutionalization). E-SOSPOL, 3(April), 27-33.

Soekanto, S. (2017). Sosiologi suatu pengantar, Revisi. Jakarta: Rajawali.

Sugiono. (2016). Metode penelitian kombinasi. Bandung: Alfabeta.

Suranto, A. 2011. Komunikasi interpersonal. Yogyakarta: Graha Ilmu. 